\title{
On the use of tritium-labelled albumin for studies of intestinal absorption
}

\author{
K. N. JEEJEEBHOY ${ }^{1}$, J. H. STEWART ${ }^{2}$, E. A. EVANS ${ }^{3}$, AND C. C. BOOTH ${ }^{4}$ \\ From the Department of Medicine, Postgraduate Medical School of London, \\ the West Middlesex Hospital, and the Radiochemical Centre, Amersham
}

\begin{abstract}
EDITORIAL SYNOPSIS Human serum albumin has been successfully labelled with tritium. It is considerably denatured in the process and has a shorter half life when given intravenously than ${ }^{131}$ I-labelled albumin. Nevertheless it is satisfactory for absorption studies, although not for turnover observations. These studies on absorption in control subjects and in patients with intestinal malabsorption indicate that the excreted radioactivity may have been derived from endogenous sources rather than from the results of malabsorption alone.
\end{abstract}

In recent years, albumin labelled with ${ }^{131}$ I has been increasingly used as a method for studying protein absorption (Lavik, Matthews, Buckaloo, Lemm, Spector, and Friedell, 1952; Chinn, Lavik, Stitt, and Buckaloo, 1952; Borgström, Dahlqvist, Lundh, and Sjövall, 1957). Although studies in vitro have demonstrated that the radioactive label may remain bound to protein or to protein residues during digestion (Lavik et al., 1952; Parkins, Dimitriadou, and Booth, 1960), the use of this material in vivo is unsatisfactory, for the ${ }^{131}$ I label may become detached in the lumen of the gut (Jeejeebhoy, 1963). Apart from conventional nitrogen balance techniques, protein absorption in man can therefore only be studied using ${ }^{15} \mathrm{~N}$-labelled proteins (Crane and Neuberger, 1960). This method provides the most physiological technique but it has the disadvantage that measurements must be made in a mass spectrometer. We have therefore investigated the possibility of using tritium-labelled albumin for absorption studies. This paper describes the labelling of human serum albumin with tritium, using the Wilzbach reaction. The resulting material was considerably altered and purification was required to extract the labelled albumin. The separation of ${ }^{3} \mathrm{H}$-albumin and the effects of hydrolysis on the stability of the tritium label in this material are described. Observations on the faecal excretion of

'Present addresses: Department of Atomic Energy, Richardson \& Cruddas Building, Byculla, Bombay, India

${ }^{2}$ Kanematsu Memorial Institute of Pathology, Sydney Hospital, Sydney, N.S.W., Australia

3Organic Department, Radiochemical Centre, Amersham, Bucks.

4Postgraduate Medical School of London, Ducane Road, London W.12. radioactivity after oral administration of ${ }^{3} \mathrm{H}$-labelled albumin in control subjects and in patients suffering from intestinal disease are reported. These observations have been compared with the results of conventional nitrogen balance techniques.

\section{MATERIALS AND METHODS}

HUMAN SERUM ALBUMIN The albumin used for labelling was obtained from the Lister Institute Laboratories, Elstree, Herts., and was prepared by ether fractionation of human plasma. It was labelled with tritium at the Radiochemical Centre, Amersham, using the Wilzbach reaction.

ELECTROPHORESIS Electrophoretic studies were carried out on cellulose acetate membrane in a veronal buffer at pH 8.6 (Smith, 1960). The strips were stained with Ponceau red.

CHROMATOGRAPHY Bidirectional ascending chromatography of albumin hydrolysates was carried out on Whatman no. 1 paper using n-butanol/acetic acid and phenol ammonia systems (Smith, 1960). Where necessary, specimens were first desalted in an electric desalter. Duplicate runs of hydrolysates with known amino-acids were also made to facilitate identification of the aminoacid spots. The chromatograms were dried and stained with $2 \%$ ninhydrin in acetone.

MEASUREMENT OF RADIOACTIVITY All samples were assayed for tritium in a Packard Tricarb liquid scintillation counter.

COUNTING OF LIQUID SPECIMENS A quantity, $0.5 \mathrm{ml}$., of the specimen to be analysed, was added to $19 \mathrm{ml}$. of Dioxane scintillation fluid. Specimens containing protein 
were counted in Dioxane gel made by adding pure silica to the scintillation fluid in a ratio of $3 \% \mathrm{w} / \mathrm{v}$. Internal standards were used throughout.

COMPOSITION OF DIOXANE FLUID The scintillation fluid was made up as follows:

2, 5, - Diphenyloxazole ........... $\mathrm{g}$.

1, 4 - bis (2,5-phenyl.-oxazolyl) benzene $150 \mathrm{mg}$.

Naphthalene (scintillation grade).....50 g.

Dioxane (Analar B.D.H.) . . . . . . . . 800 ml.

Toluene (Analar B.D.H.) . . . . . . $200 \mathrm{ml}$.

Ethanol ................... $30 \mathrm{ml}$.

COUNTING OF CELlULOSE ACETATE STRIPS OR PAPER CHROMATOGRAMS Standard lengths cut from strips of cellulose acetate or spots cut from paper chromatograms were placed flat at the bottom of containers and covered with $19 \mathrm{ml}$. of scintillation fluid (Packard technical bulletin, June, 1961). The counts obtained from chromatographic spots were compared with a standard prepared by spotting a volume of hydrolysate or digest equal to the total amount applied to the chromatogram (usually $100 \mu \mathrm{l}$.); these were then stained with $2 \%$ ninhydrin in the same way as the chromatograms.

MEASUREMENT OF ALBUMIN ABSORPTION The procedure was as follows:-

Radioactive test dose Purified ${ }^{3} \mathrm{H}$-labelled albumin, $100 \mu \mathrm{c}$., was added to $25 \mathrm{~g}$. of unlabelled albumin dissolved in $300 \mathrm{ml}$. of distilled water. The test dose was fed to the patients after an overnight fast, and no food was taken for a further two to four hours.

Faecal collections Patients were usually studied in a metabolic unit. The stools were collected for six days in two successive three-day periods; they were then homogenized and aliquots were dried.

Assay of ${ }^{3} \mathrm{H}$ in faecal samples Tritium in faeces was estimated by the perchloric acid technique described by Belcher (1960). The procedure was as follows: $2 \mathrm{~g}$. of the dried faecal specimens (or $5 \mathrm{~g}$. in the case of wet specimens) was refluxed with 10 to $15 \mathrm{ml}$. of concentrated nitric acid for two to four hours. Each sample was then divided into two equal volumes in separate Kjeldahl flasks. To one flask, an internal standard prepared from the radioactive test dose was added; an equal volume of distilled water was added to the other. Three $\mathrm{ml}$. of perchloric acid was then added to each flask and the mixture was heated gently in a distilling Kjeldahl flask connected to a Leibig condenser and collecting tube until white fumes appeared and complete oxidation occurred. The distillate of acid and water was then replaced in the Kjeldahl flask and again boiled until a few millilitres of clear fluid had distilled over. Equal volumes of the distillates were neutralized with the same volumes of strong ammonia; volumes of $0.5 \mathrm{ml}$. were then counted as already described. Different degrees of quenching between samples were assessed by recounting after adding known standards. There was no significant difference in the results obtained when observations were made on wet or dry specimens from the same patient.

Plasma and urine radioactivity The amounts of radio- activity found in plasma and urine after the oral test dose were also measured; since the counting rates were too low to allow accurate interpretation, the results have been omitted.

Faecal nitrogen estimations Faecal nitrogen in the two successive three-day faecal collections was estimated according to the methods described by King and Wootton (1956). In selected patients, faecal nitrogen estimations were made on varying dietary protein intakes.

\section{PATIENTS STUDIED}

Six control subjects (cases 1 to 6 ), whose intestinal function was assumed to be normal, were studied. Studies were also carried out on five patients with gastrectomy (cases 7 to 11), four patients with idiopathic steatorrhoea (cases 12 to 15 ), three patients with partial resection of the small intestine (cases 16 to 18 ), one patient with Crohn's disease involving the distal ileum (case 19), and one patient with pancreatic steatorrhoea (case 20).

\section{PREPARATION OF ${ }^{3} \mathrm{H}$-LABELLED ALBUMIN}

LABELLING WITH TRITIUM One gram of albumin was exposed to 7 curies of ${ }^{3} \mathrm{H}$ gas for 10 days at $0^{\circ} \mathrm{C}$. and a pressure of $67 \mathrm{~mm}$. of mercury. The resulting material was freed from labile ${ }^{3} \mathrm{H}$ by dissolving in water and freeze-drying the solution.

ELECTROPHORESIS OF LABELLED MATERIAL The ${ }^{3} \mathrm{H}$ labelled protein obtained was first subjected to electrophoresis on cellulose acetate. It was clear that the labelling procedure had markedly denatured the albumin in the original material, for unlike the unlabelled parent substance it no longer formed a single band. The radioactivity did not correspond only to the position of the albumin fraction, indicating that a number of the breakdown products of the starting material were also labelled.

SEPARATION OF LABELled ALBUMIN A glass column, $1 \mathrm{~cm}$. in diameter, was packed with DEAE Sephadex A-25 to a depth of $10 \mathrm{~cm}$. (Flodin, 1961). The column was adjusted to a $p \mathrm{H}$ of 6.8 with $0.01 \mathrm{M}$ phosphate buffer. Fifty $\mathrm{mg}$. of crude ${ }^{3} \mathrm{H}$-labelled material was now applied to the column and successively eluted with $\mathrm{NaCl}$, increasing in concentration from $0.01 \mathrm{M}$ to $0.17 \mathrm{M}$ by steps of $0.02 \mathrm{M}$. The protein content of the eluate was estimated in a Unicam spectrophotometer at a wave length of $280 \mathrm{~m} \mu$. Figure 1 illustrates the results. It was found that albumin was eluted at a concentration of $0 \cdot 17 \mathrm{M}$ sodium chloride (Fig. 1).

The specimen with the peak concentration was collected and subjected to electrophoresis on cellulose acetate. The protein in this specimen formed a single band in the position of albumin and the radioactivity was now confined to this albumin band. The material had a specific activity of $30 \mu \mathrm{c}$. per $\mathrm{mg}$. The radioactivity in this material was not dialysable. 


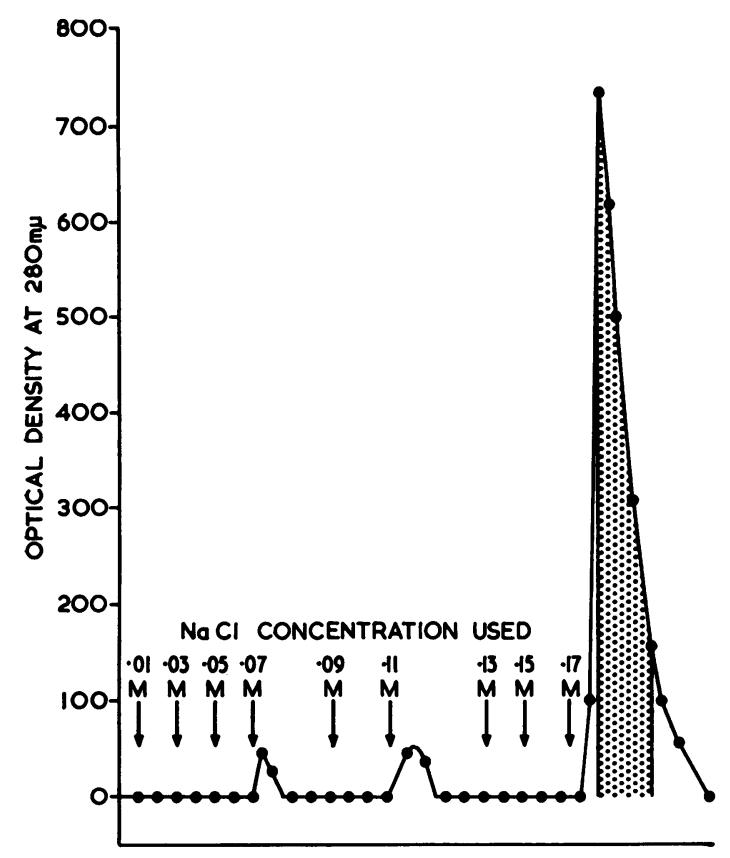

FIG. 1. Effect of elution of ${ }^{3} \mathrm{H}$-labelled protein from DEAE Sephadex column using $\mathrm{NaCl}$ increasing in concentration from 0.01 to $0.17 \mathrm{M}$.

\section{EFFECTS OF HYDROLYSIS \\ ON ${ }^{3}$ H-LABELLED ALBUMIN}

ACID HYDROLYSIS IN VITRO Purified ${ }^{3} \mathrm{H}$ albumin, $50 \mathrm{mg}$., was hydrolysed by refluxing with $20 \mathrm{ml}$. of $5 \mathrm{~N}$ hydrochloric acid in a boiling water bath for 24 hours. The hydrolysate was neutralized with $5 \mathrm{~N} \mathrm{NaOH}$. Then $100 \mu \mathrm{l}$. was subjected to bidirectional chromatography. The amounts of radioactivity recovered from the spots formed by a variety of amino-acids are shown in Table $I$.

\section{TABLE I}

DISTRIBUTION OF RADIOACTIVITY IN AMINO-ACID CHROMATOGRAM OF ACTD HYDROLYSATE OF ${ }^{3}$ H-LABELLED ALBUMIN

\begin{tabular}{lc} 
Amino-acid & Percentage of Radioactivity \\
\hline Leucine & $8 \cdot 5$ \\
Phenylalanine & $8 \cdot 3$ \\
Valine & $9 \cdot 9$ \\
Proline & $18 \cdot 0$ \\
Aspartic acid & $0 \cdot 9$ \\
Glutamic acid & $4 \cdot 6$ \\
Glycine & $3 \cdot 8$ \\
Threonine & $0 \cdot 9$ \\
Alanine & $2 \cdot 6$ \\
Balanine & $4 \cdot 2$ \\
Tyrosine & $6 \cdot 6$ \\
Glutamine & $1 \cdot 4$ \\
Arginine & $1 \cdot 3$ \\
Lysine & $1 \cdot 2$ \\
Origin & $4 \cdot 5$ \\
Total recovery & 76.7
\end{tabular}

It can be seen that these amino-acids are all labelled, the greatest labelling being over the proline spot. This experiment is qualitative and the total recovery of $76.7 \%$ cannot be interpreted quantitatively.

COMPARISON OF RATE OF DIGESTION OF LABELLED AND UNLABELLED ALBUMIN IN VITRO Four grams of unlabelled human serum albumin and $100 \mu \mathrm{c}$. of ${ }^{3} \mathrm{H}$-labelled albumin were dissolved in $50 \mathrm{ml}$. of $0.01 \mathrm{~N} \mathrm{NaOH}$ and heated in a boiling water bath for 10 minutes. This procedure partially denatures the protein and therefore facilitates subsequent tryptic digestion. Four ml. of this solution was pipetted into each of three test tubes and mixed with $0.2 \mathrm{M}$ tris buffer at $p H \mathbf{H} \cdot 5$. One millilitre of distilled water was added to the first tube, to be used as a standard, and $1 \mathrm{ml}$. of human duodenal juice was added to each of the remaining two tubes. The protein in the standard tube was precipitated immediately by adding $6 \mathrm{ml}$. of $10 \%$ trichloractic acid; the two other tubes were treated similarly after digestion at $37^{\circ} \mathrm{C}$. for 20 and 40 minutes respectively. The protein content and the ${ }^{3} \mathrm{H}$ activity in the precipitates were measured and the specific activities were calculated as counts per milligram. The results are given in Table II. These show that the ratio of the labelled to the unlabelled albumin did not alter during enzymatic hydrolysis, even though as much as $65 \%$ of the protein had undergone digestion. The labelled albumin therefore behaved similarly to the unlabelled material in this experiment.

\section{TABLE II}

COMPARISON OF RATE OF DIGESTION OF ${ }^{3} \mathrm{H}$-LABELLED AND UNLABELLED ALBUMIN IN VITRO

\begin{tabular}{lcc} 
Digestion Period & $\begin{array}{l}\text { Undigested Protein } \\
\text { (\% of total) }\end{array}$ & $\begin{array}{l}\text { Specific Activity } \\
\text { (counts per } \text { mg.) }\end{array}$ \\
\hline Before & 100 & 62 \\
After 20 minutes & 67 & 68 \\
After 40 minutes & 35 & 63
\end{tabular}

ENZYMATIC HYDROLYSIS IN VIVO ${ }^{3} \mathrm{H}$-labelled albumin, $100 \mu \mathrm{c}$., was fed to two rats. The animals were killed after 15 minutes and the intestinal tract washed out. Volumes of the washings, each of $100 \mu \mathrm{l}$., were subjected to bidirectional chromatography as already described.

An illustration of the results of chromatography and radioactive measurements of amino-acids following this procedure in one of these animals is given in Table III. Since most of the radioactivity remained bound to proteins, peptides, or aminoacids, it is unlikely that intestinal digestion removes the ${ }^{3} \mathrm{H}$-label from albumin or its component aminoacids in vivo in the rat. 
TABLE III

DISTRIBUTION OF RADIOACTIVITY IN AMINO-ACID CHROMATOGRAM OF INTESTINAL DIGEST OF ${ }^{3}$ H-LABELLED ALBUMIN IN VIVO

\begin{tabular}{lc} 
Amino-acid & Percentage of Radioactivity \\
\hline Leucine & $10 \cdot 3$ \\
Phenylalanine & $11 \cdot 5$ \\
Valine & $8 \cdot 0$ \\
Proline & $8 \cdot 8$ \\
Aspartic acid & $1 \cdot 3$ \\
Glutamic acid & $12 \cdot 0$ \\
Glycine & $1 \cdot 2$ \\
Threonine & $2 \cdot 6$ \\
Alanine & $1 \cdot 8$ \\
Tyrosine & $1 \cdot 9$ \\
Arginine and lysine & $6 \cdot 8$ \\
Origin & $27 \cdot 0$ \\
Total recovery & $93 \cdot 2$
\end{tabular}

FAECAL EXCRETION AFTER ORAL ADMINISTRATION OF ${ }^{3}$ H-LABELLED ALBUMIN IN MAN

CONTROL SUBJECTS The six control subjects (cases 1 to 6$)$ received the standard oral dose of $100 \mu \mathrm{c}$. of ${ }^{3} \mathrm{H}$-labelled albumin together with $25 \mathrm{~g}$. unlabelled material. The amounts of radioactivity excreted in the stools are shown in Table IV.

These subjects excreted between 2.6 and $16.9 \%$ of the oral dose (mean 10.4\%); the calculated absorption was therefore from 83.1 to $97.4 \%$. In five subjects (cases $1,2,4,5$, and 6) maximum excretion of the radioactivity occurred during the first three-day period.
Faecal nitrogen ranged from 0.6 to $2 \cdot 4 \mathrm{~g}$. per day in these subjects.

GASTRECTOMY The results of studies in the five patients who had undergone gastrectomy are given in Table $\mathrm{V}$. Table $\mathrm{V}$ also includes serum albumin levels and faecal nitrogen excretion in these patients.

In all but one of these five patients the total excretion of radioactivity was greater than in any of the control subjects. In three patients (cases 7 to 9) the greatest excretion of radioactivity occurred in the second three-day faecal collection (Table V). A repeat test was carried out on one of these patients (case 7), $\mathrm{Cr}^{51}$ being given as a marker together with the test dose. Although $90 \%$ of the $\mathrm{Cr}^{51}$ marker was excreted during the first three days, maximum excretion of the tritium again occurred during the second three-day period. In the other two patients (cases 10 and 11) maximal excretion occurred in the first three days, as in the control subjects. The first of these patients (case 10), whose excretion of ${ }^{3} \mathrm{H}$ was greater than normal, also excreted an amount greater than the controls during the second three days. The second (case 11) excreted normal amounts of radioactivity.

Faecal nitrogen excretion There was a good correlation between the faecal nitrogen estimations and the faecal excretion of radioactivity in these patients, the greatest excretion occurring in the patient with the highest faecal nitrogen (case 7 ,

TABLE IV

ABSORPTION OF ${ }^{3}$ H-LABELLED ALBUMIN IN CONTROL SUBJECTS

\begin{tabular}{|c|c|c|c|c|c|}
\hline \multirow[t]{2}{*}{ Case No. } & \multirow[t]{2}{*}{ Diagnosis } & \multicolumn{2}{|c|}{$\begin{array}{l}\text { Faecal Excretion of Radioactivity } \\
(\% \text { of dose })\end{array}$} & \multirow[t]{2}{*}{$\begin{array}{l}\text { Percentage of Dose } \\
\text { Absorbed }\end{array}$} & \multirow[t]{2}{*}{$\begin{array}{l}\text { Faecal Nitrogen Excretion } \\
\text { (g./day) }\end{array}$} \\
\hline & & First 3 Days & Second 3 Days & & \\
\hline 1 & Convalescent bronchopneumonia & $2 \cdot 4$ & 0.2 & $97 \cdot 4$ & 0.6 \\
\hline 2 & Convalescent bronchopneumonia & $3 \cdot 3$ & $0 . \overline{0}$ & $96 \cdot 7$ & $1 \cdot 1$ \\
\hline 3 & Ischaemic heart disease & $6 \cdot 5$ & $6 \cdot 6$ & 86.9 & 1.4 \\
\hline 4 & Functional dyspepsia & $10 \cdot 4$ & $3 \cdot 5$ & $86 \cdot 1$ & $2 \cdot 4$ \\
\hline 5 & Ischaemic heart disease & $15 \cdot 1$ & 0.6 & $84 \cdot 3$ & $1 \cdot 4$ \\
\hline 6 & Chronic duodenal ulcer & $12 \cdot 7$ & $4 \cdot 2$ & $83 \cdot 1$ & 0.4 \\
\hline
\end{tabular}

TABLE V

ABSORPTION OF ${ }^{3} \mathrm{H}$-LABELLED ALBUMIN AFTER GASTRECTOMY

\begin{tabular}{|c|c|c|c|c|c|c|}
\hline \multirow[t]{2}{*}{ Case No. } & \multirow[t]{2}{*}{ Diagnosis } & \multicolumn{2}{|c|}{$\begin{array}{l}\text { Faecal Excretion of Radioactivity } \\
(\% \text { of Dose })\end{array}$} & \multirow[t]{2}{*}{$\begin{array}{l}\text { Percentage of Dose } \\
\text { Absorbed }\end{array}$} & \multirow[t]{2}{*}{$\begin{array}{l}\text { Faecal Nitrogen } \\
\text { Excretion (g./day) }\end{array}$} & \multirow[t]{2}{*}{$\begin{array}{l}\text { Serum Albumin } \\
(g . \%)\end{array}$} \\
\hline & & First 3 Days & Second 3 Days & & & \\
\hline 7 & Partial gastrectomy (Polya) & $\begin{array}{c}10 \cdot 3 \\
9 \cdot 6^{1}\end{array}$ & $\begin{array}{l}28 \cdot 0 \\
25 \cdot 4\end{array}$ & $\begin{array}{l}61 \cdot 7 \\
65 \cdot 0\end{array}$ & $\begin{array}{l}6 \cdot 7 \\
6 \cdot 3\end{array}$ & $2 \cdot 4$ \\
\hline 8 & Partial gastrectomy (Polya) & $9 \cdot 8$ & $17 \cdot 6$ & $72 \cdot 5$ & $3 \cdot 4$ & $3 \cdot 0$ \\
\hline 9 & Partial gastrectomy (Polya) & 0.6 & $25 \cdot 6$ & 73.8 & 3.4 & $2 \cdot 7$ \\
\hline 10 & $\begin{array}{l}\text { Subtotal gastrectomy and } \\
\text { pancreatectomy }\end{array}$ & $27 \cdot 6$ & 8.9 & $63 \cdot 5$ & $\begin{array}{l}\text { (a) } 5 \cdot 9^{2} \\
\text { b) } 5 \cdot 5\end{array}$ & $3 \cdot 7$ \\
\hline 11 & Partial gastrectomy (Polya) & $16 \cdot 9$ & 0.0 & $83 \cdot 1$ & $2 \cdot 1$ & $3 \cdot 8$ \\
\hline
\end{tabular}

${ }^{1} \mathrm{Cr}^{51}$ marker given with oral test dose.

(a) Dietary nitrogen 7 g. per day.

(b) Dietary nitrogen 19 g. per day. 


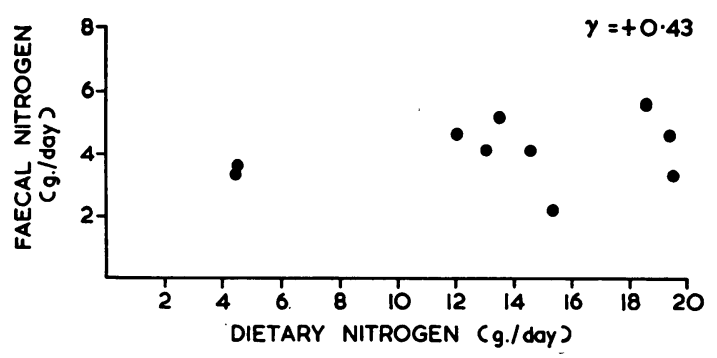

FIG. 2. Relationship between dietary and faecal nitrogen in a patient with hypoalbuminaemia following partial gastrectomy (case 7).

Table V), who also had severe steatorrhoea and marked hypoalbuminaemia. Further faecal nitrogen estimations on varying dietary intakes in this patient revealed no relationship between dietary nitrogen intake and faecal nitrogen excretion (Fig. 2). In one other patient (case 10) faecal nitrogen excretion was studied on two different levels of nitrogen intake. There was an insignificant change in faecal nitrogen when his oral nitrogen intake was increased from 7 g. to 19 g. per day (Table V).

IDIOPATHIC STEATORRHOEA The results in the four patients with idiopathic steatorrhoea are given in Table VI. Three of these patients (cases 13 to 15) were selected because they had hypoanabolic hypoalbuminaemia (Jeejeebhoy, 1964).
The four patients all excreted more radioactivity than the control subjects, the percentage excretion ranging from 29.5 to 63.3 . Maximum excretion occurred during the second three days in three of the four patients (cases 12,14, and 15).

Faecal nitrogen excretion Faecal nitrogen excretion was increased in all these patients. In one patient (case 12) faecal nitrogen was measured on two different dietary intakes. Although the nitrogen intake was $0.9 \mathrm{~g}$. per day during the first balance and $12.8 \mathrm{~g}$. per day during the second, faecal nitrogen did not alter significantly. Furthermore he excreted more nitrogen than in the diet while on an intake of $0.9 \mathrm{~g}$. per day (Table VI).

INTESTINAL RESECTION, CROHN'S DISEASE, AND PANCREATIC STEATORRHOEA The results in the remaining patients are given in Table VII.

Two of the patients with resection of the distal small intestine (cases 16 and 17) excreted abnormally high amounts of radioactivity in the faeces (26.4 and $44.1 \%$ respectively); in both these patients maximal excretion occurred in the first three days. Faecal nitrogen levels were slightly raised in one patient (case 16) but normal in the other (case 17). The third patient (case 18) had only lost four feet of the terminal ileum; ${ }^{3} \mathrm{H}$ excretion after the oral test dose of labelled albumin was normal in this patient. The patient with Crohn's disease involving

TABLE VI

ABSORPTION OF ${ }^{3} \mathrm{H}$-LABELLED ALBUMIN IN IDIOPATHIC STEATORRHOEA

\begin{tabular}{|c|c|c|c|c|c|}
\hline \multirow[t]{2}{*}{ Case No. } & \multicolumn{2}{|c|}{ Faecal Excretion of Radioactivity ( $\%$ of dose) } & \multirow{2}{*}{$\begin{array}{l}\text { Percentage of Dose } \\
\text { Absorbed }\end{array}$} & \multirow{2}{*}{$\begin{array}{l}\text { Faecal Nitrogen } \\
\text { Excretion (g./day) }\end{array}$} & \multirow[t]{2}{*}{ Serum Albumin $(g . \%)$} \\
\hline & First 3 Days & Second 3 Days & & & \\
\hline 12 & $5 \cdot 2$ & $23 \cdot 8$ & $71 \cdot 0$ & $\begin{array}{r}1 \text { (a) } 4 \cdot 4 \\
\text { (b) } 4 \cdot 2\end{array}$ & $3 \cdot 7$ \\
\hline $\begin{array}{l}13 \\
14 \\
15\end{array}$ & $\begin{array}{r}24 \cdot 8 \\
24 \cdot 2 \\
5 \cdot 5\end{array}$ & $\begin{array}{l}12 \cdot 7 \\
39 \cdot 1 \\
24 \cdot 0\end{array}$ & $\begin{array}{l}62 \cdot 5 \\
36 \cdot 7 \\
70 \cdot 5\end{array}$ & $\begin{array}{l}3 \cdot 2 \\
3 \cdot 5 \\
4 \cdot 1\end{array}$ & $\begin{array}{l}2 \cdot 9 \\
2 \cdot 8 \\
3 \cdot 1\end{array}$ \\
\hline
\end{tabular}

'(a) Dietary nitrogen 0.9 g. daily.

(b) Dietary nitrogen $12.8 \mathrm{~g}$. daily.

TABLE VII

ABSORPTION OF ${ }^{3} \mathrm{H}$-LABELLED ALBUMIN AFTER INTESTINAL RESECTION, IN CROHN'S DISEASE, AND IN PANCREATIC STEATORRHOEA

Case No. Diagnosis
Faecal Excretion of Radioactivity (\% of dose)

First 3 Days $\quad$ Second 3 Days

$\begin{array}{rllll}20.4 & 6.0 & 73.6 & 3.3 & 2.8 \\ 39.1 & 5.0 & 55.9 & 1.1 & 3.8 \\ 4.9 & 1.7 & 93.4 & 1.4 & 4.2 \\ 4.9 & 0.0 & 95.1 & 2.3 & 2.5 \\ 16.5 & 5.5 & 78.0 & 2.5 & 2.0\end{array}$


the terminal ileum (case 19) also excreted normal amounts of radioactivity, but there was a slightly increased excretion in the final patient (case 20) who had pancreatic steatorrhoea.

\section{DISCUSSION}

The results given in this paper demonstrate that it is possible to label human serum albumin with tritium by the Wilzbach reaction. The procedure considerably alters the protein but it is possible to separate the labelled albumin by elution from a DEAE Sephadex column. Hydrolysis experiments, both in vivo and in vitro, show that a wide variety of the constituent amino-acids are labelled with tritium. Furthermore, the rate of digestion of the labelled albumin is similar to that of unlabelled material. It is likely that the labelled albumin is considerably denatured, for the ${ }^{3} \mathrm{H}$-labelled material had a shorter half-life when injected intravenously than ${ }^{131}$ I-labelled albumin. A simultaneous study using intravenously injected ${ }^{131}$ I-labelled albumin and ${ }^{3} \mathrm{H}$-labelled material in a control subject revealed that the half-life of the ${ }^{3} \mathrm{H}$-labelled albumin was only five days compared with a half-life of 20 days for the ${ }^{131}$ I-labelled material. Albumin labelled with tritium in this way is therefore unsatisfactory for turnover studies. This finding, however, does not invalidate its use for absorption studies, since hydrolysis yields labelled amino-acids.

With certain reservations, these observations suggest that for the purpose of studying intestinal absorption, tritium may prove to be a more satisfactory radioactive label for albumin than others hitherto described. Using an oral test dose of $25 \mathrm{~g}$. of albumin together with $100 \mu \mathrm{c}$. of the ${ }^{3} \mathrm{H}$-labelled protein, the control subjects excreted between 2.6 and $16.9 \%$ of the dose in the faeces, the greatest excretion occurring during the first three days (Table V). The amount of radioactivity excreted by these subjects was larger than expected. This may possibly be because of the large amount of protein given, together with the volume of fluid in which it was fed. It is known that fluids pass through the intestinal tract more rapidly than solids and it is possible that smaller amounts would be excreted if the test dose was given in a more physiological manner together with a meal.

The patients with gastrectomy excreted more radioactivity in the faeces than the control subjects, and there was a good correlation between the faecal excretion of tritium and the faecal nitrogen (Table V). In these patients most of the radioactivity was excreted in the second three-day period. Crane and Neuberger (1960) observed a similar pattern of excretion in studying the faecal elimination of
${ }^{15} \mathrm{~N}$-labelled proteins after oral dosage in patients with intestinal malabsorption and suggested that this might represent an excretion from endogenous sources. It has long been suspected that faecal nitrogen may be largely of endogeneous origin (Voit, 1884; McCrudden and Fales, 1912) and the nitrogen balances performed on two of these patients (cases 7 and 10) on varying dietary intakes, which show that the raised faecal nitrogen was not influenced by the dietary nitrogen (Table V, Fig. 4), strongly support this hypothesis. It is therefore possible that the increased excretion of tritium in the second three-day period is due to an excretion of tritium-labelled proteins or amino-acids from endogenous sources, rather than the result of malabsorption. Measurement of faecal excretion of radioactivity after oral administration of ${ }^{3} \mathrm{H}$ labelled protein may therefore be unsatisfactory as a method of measuring protein absorption in such patients. However, the faecal loss of proteins or amino-acids, derived from endogenous excretion, may possibly play a part in causing the loss of weight which so commonly follows gastric operations. In these patients this was not associated with albumin loss into the intestine, since albumin turnover studies carried out with oral amberlite resin showed either normal or reduced faecal excretion of radioactivity (Jeejeebhoy, 1964).

The four patients with idiopathic steatorrhoea also excreted more radioactivity than the control subjects. As in the gastrectomy patients, the excretion in the second three-day period was often greater than in the first. The suggestion that this pattern of excretion may again represent loss of protein or of amino-acid from endogenous sources is supported by the observation that one of these patients (case 12) excreted as much as $4.5 \mathrm{~g}$. of nitrogen per day in the stool during a balance period when he was receiving only $0.9 \mathrm{~g}$. of protein daily (Table VI).

The results in the two patients subjected to extensive resection of the distal small intestine (cases 16 and 17, Table VIII) were different. Maximal excretion occurred during the first three days; this pattern of excretion of radioactivity after an oral dose may well indicate malabsorption. One of these patients (case 17) excreted as much as $45 \%$ of the oral dose in the stools, of which the greater part was excreted in the first three days. The large percentage of the dose excreted by this patient is difficult at first to reconcile with her normal faecal nitrogen excretion. This discrepancy is again likely to be due to the use of a fluid oral test dose which might be expected to pass rapidly through the small amount of residual small intestine, whereas food protein, as has been demonstrated after intestinal resection 
(Althausen, Uyeyama, and Simpson, 1949), may behave differently.

At the moment, these conclusions must be preliminary. The possibility that the high excretion of labelled material in the faeces in the second three-day period represents an excretion from endogenous sources would invalidate the use of ${ }^{3} \mathrm{H}$-albumin for absorption studies using the conventional balance methods described in this paper. The labelled protein may, however, produce a method for investigating the origin of the faecal nitrogen in health and disease.

\section{SUMMARY}

Human serum albumin has been successfully labelled with tritium using the Wilzbach reaction. The resulting material is considerably denatured but labelled albumin may be extracted by elution from a DEAE Sephadex column.

One hundred microcuries of labelled albumin together with $25 \mathrm{~g}$. of unlabelled albumin was given orally to control subjects and to patients suffering from a variety of gastrointestinal diseases associated with intestinal malabsorption. Faecal excretion of radioactivity was measured during two successive three-day periods after the oral dose of labelled albumin was given. The pattern of excretion in many of the patients suffering from intestinal malabsorption suggested that much of the excreted radioactivity may have been derived from endogenous sources rather than the result of malabsorption alone. This conclusion suggests that ${ }^{3} \mathrm{H}$-labelled albumin may be of greater value for studying the origin and nature of the faecal nitrogen in many patients than for measuring protein absorption.

We wish to thank Dr. N. F. Coghill for the opportunity of studying patients who were under his care, Dr. W.
d'A. Maycock for supplies of human serum albumin for labelling, Dr. Michael Lubran for helpful suggestions on the purification of labelled albumin, and Dr. E. H. Belcher for assistance with counting techniques. Nitrogen balance studies were carried out by Dr. H. Anstell. One of us (K.N.J.) was in receipt of a grant from the Medical Research Council to whom we express our gratitude.

\section{REFERENCES}

Althausen, T. L., Uyeyama, K., and Simpson, R. G. (1949). Digesti on and absorption after massive resection of the small intestine. I. Utilization of food from a 'natural' versus a 'synthetic' diet and a comparison of intestinal absorption tests with nutritional balance studies in a patient with only $45 \mathrm{~cm}$. of small intestine. Gastroenterology, 12, 795-807.

Belcher, E. H. (1960). The assay of tritium in biological material by wet oxidation with perchloric acid followed by liquid scintillation counting. Phys. in med. Biol., 5, 49-56.

Borgström, B., Dahlqvist, A., Lundh, G., and Sjövall, J. (1957). Studies of intestinal digestion and absorption in the human. J. clin. Invest., 36, 1521-1536.

Chinn, A. B., Lavik, P. S., Stitt, R. M., and Buckaloo, G. W. (1952) Use of ${ }^{131} I$-labeled protein in the diagnosis of pancreatic insufficiency. New Engl. J. Med., 247, 877-880.

Crane, C. W., and Neuberger, A. (1960). Absorption and elimination of ${ }^{16} \mathrm{~N}$ after administration of isotopically labelled yeast protein and yeast protein hydrolysate to adult patients with coeliac disease. Brit. med. J., 2, 815-823 and 888-894.

Flodin, P. (1961). Methodological aspects of gel flltration with special reference to desalting operations. J. Chromatog., 5, 103-115.

Jeejeebhoy, K. N. (1963). A study of albumin metabolism in gastrointestinal disease. Ph.D. Thesis, University of London.

- (1964). Hypoanabolic hypoalbuminaenia in gastrointestinal disease. Brit. med. J., 1, 30-35.

King, E. J., and Wootton, I. D. P. (1956). Microanalysis in Medical Biochemistry, 3rd ed. Churchill, London.

Lavik, P. S., Matthews, L. W., Buckaloo, G. W., Lemm, F. J., Spector, S. and Friedell, H. L. (1952). Use of ${ }^{131}$ I-labeled protein in the study of protein digestion and absorption in children with and without cystic fibrosis of the pancreas. Pediatrics, 10, 667-676.

McCrudden, F. H., and Fales, H. L. (1912). Complete balance studies of nitrogen, sulphur, phosphorus, calcium and magnesium in intestinal infantilism. J. exp. Med., 15, 450-456.

Parkins, R. A., Dimitriadou, A., and Booth, C. C. (1960). The rates and sites of absorption of ${ }^{181}$ I-labelled albumin and sodium ${ }^{131} \mathrm{I}$ in the rat. Clin. Sci., 19, 595-604.

Smith, I. (1960). Chromatographic and Electrophoretic Techniques. London, Heinemann.

Voit, C. (1894). Uber die Beziehungen der Galleabsonderung zum Gesammtstoffwechel im thierischen Organismus. Z. Biol., 12, 523-561. 